\title{
Lifelong learning activities for older adults: a scoping review protocol
}

\author{
Atividades de aprendizagem ao longo da vida para idosos: protocolo de scoping review \\ Actividades de aprendizaje permanente para adultos mayores: un protocolo de revisión del alcance
}

Received: 10/18/2021 | Reviewed: 10/25/2021 | Accept: 10/25/2021| Published: 10/29/2021

\author{
Karina de Lima Flauzino \\ ORCID: https://orcid.org/0000-0001-8062-3336 \\ University of Sao Paulo, Brazil \\ E-mail: karinaflauzino@usp.br \\ Henrique Manuel Pires Teixeira Gil \\ ORCID: https://orcid.org/0000-0001-9280-8872 \\ Castelo Branco Polytechnic Institute, Portugal \\ E-mail: hteixeiragil@ipcb.pt \\ Samila Sathler Tavares Batistoni \\ ORCID: https://orcid.org/0000-0002-8587-8298 \\ University of Sao Paulo, Brazil \\ E-mail: samilabatistoni@gmail.com \\ Maraiza Oliveira Costa \\ ORCID: https://orcid.org/0000-0001-6523-5634 \\ University of Sao Paulo, Brazil \\ E-mail:maraizacosta@hotmail.com \\ Meire Cachioni \\ ORCID: http://orcid.org/0000-0001-5220-410X \\ University of Sao Paulo, Brazil \\ E-mail: meirec@usp.br
}

\begin{abstract}
Objective: To map lifelong learning activities for the elderly to understand how this paradigm has been incorporated into practical actions. Methodology: A scoping review type survey will be conducted in the literature published in English in five databases between the period 1972 to 2020. The mnemonic PCC (Population, Concept and Context) will guide the search strategy, the selection and extraction process of the studies, which will be conducted by two authors independently. Peer-reviewed articles that present the conceptual notion of lifelong learning as the central theme of the study, the target audience of men and women aged 50 and over and the description of formal educational activities will be included for the analysis, non-formal and informal. The review will include articles with a qualitative, quantitative or mixed methodological approach. The evidence will be organized in a specific form containing bibliometric data and the main characteristics of the studies, as well as specific information to answer the objectives of this scoping review. Results: will be presented in descriptive synthesis accompanied by tables and diagrams.
\end{abstract}

Keywords: Lifelong learning; Older adults; Later life learning; Educational activities; Scoping review.

\section{Resumo}

Objetivo: Mapear as atividades de aprendizagem ao longo da vida para os idosos para compreender como este paradigma tem sido incorporado em ações práticas. Metodologia: Uma pesquisa de revisão do tipo scoping review será conduzida na literatura publicada em inglês em cinco bases entre o período de 1972 a 2020. O mnemônico PCC (População, Conceito e Contexto) norteará a estratégia de busca, o processo de seleção e extração dos estudos, os quais serão conduzidos por dois autores de maneira independente. Serão incluídos para a análise os artigos revisados por pares que apresentarem a noção conceitual da aprendizagem ao longo da vida como temática central do estudo, o público-alvo de homens e mulheres com idade de 50 anos ou mais e a descrição de atividades educativas formais, não formais e informais. A revisão incluirá artigos com abordagem metodológica qualitativa, quantitativa ou mista. As evidências serão organizadas em um formulário específico contendo os dados bibliométricos e as principais características dos estudos, bem como as informações específicas para responder os objetivos desta scoping review. Resultados: serão apresentados em síntese descritiva acompanhada de tabelas e diagramas.

Palavras-chave: Aprendizagem ao longo da vida; Idosos; Aprendizagem tardia; Atividades educativas; Revisão de escopo.

\section{Resumen}

Objetivo: Mapear las actividades de aprendizaje a lo largo de la vida para que los adultos mayores comprendan cómo este paradigma se ha incorporado a las acciones prácticas. Metodología: Se realizará una encuesta tipo scoping review 
en la literatura publicada en inglés en cinco bases de datos entre el período 1972 a 2020 . El mnemónico PCC (Population, Concept and Context) guiará la estrategia de búsqueda, el proceso de selección y extracción de los estudios, que será realizado por dos autores de forma independiente. Se incluirán para el análisis artículos revisados por pares que presenten la noción conceptual de aprendizaje a lo largo de toda la vida como tema central del estudio, el público objetivo de hombres y mujeres de 50 años o más y la descripción de las actividades educativas formales, no formales e informales. La revisión incluirá artículos con enfoque cualitativo, cuantitativo o metodológico mixto. La evidencia se organizará en un formato específico que contendrá datos bibliométricos y las principales características de los estudios, así como información específica para dar respuesta a los objetivos de esta revisión de alcance. Resultados: se presentarán en síntesis descriptiva acompañada de tablas y diagramas.

Palabras clave: Aprendizaje permanente; Personas mayores; Aprendizaje posterior en la vida; Actividades educativas; Revisión del alcance.

\section{Introduction}

The lifelong learning paradigm suggests a new educational culture which integrates and complements different learning modes: formal, non-formal and informal. In this sense, learning is considered to occur at any time and place, from birth to the end of life, in a flexible and constructive manner for all ages and across all contexts of life (Delors et al., 1996). Lifelong learning refers, not to a technical term with a precise meaning but, to a cultural term which requires a wide understanding of the relations between the individuals and the socio-political systems (Federighi, 1999). The propagation of the concept of lifelong learning can be justified by globalisation, the need for new knowledge skills, the emergence of new technologies as well as by demographic changes, in an attempt to meet the demands of a world in a constant state of change (UNESCO, 2014).

It is possible to identify two main generations in the conceptual development of lifelong learning (Wang, Yuan \& Weidlich, 2017). The first refers to the 1970s, especially with the publication of the Faure Report, Learning to Be: The World of Education Today and Tomorrow, in 1972 by the United Nations Educational, Scientific and Cultural Organisation (UNESCO). Inspired by humanistic ideals, the Faure Report presents lifelong education in the logic of learning how to be, considering man as an unfinished being in a constant learning process (Faure et al, 1972). However, in the following years, few investments regarding this educational perspective were observed in international engagements (Dehmel, 2006). Lifelong learning only reappeared on political agendas in the 1990s, as represented in a second generation, being highlighted by the publication of the Delors Report, Learning: The Treasure Within, by UNESCO in 1996. The Delors Report extended the strategic value of education so to achieve complete development across individual, economic, political, social and cultural aspects. The change from the term lifelong education to lifelong learning, observed between the Faure and Delors reports, meant major consistency and understanding of the learning process, including in addition to the temporal dimension (lifelong), the notion of learning across the whole life compass (life-wide) (Elfert, 2015).

According to Delors et al. (1996), education is a continuous process of political and social emancipation, which, in turn, directly impacts on the development of the individuals and their communities. In this regard, the right to education for older adults is reinforced as they are recognised as learners with potential to develop themselves throughout their lives and to benefit from learning activities (Tam, 2018). Moreover, the population ageing megatrend, as observed worldwide, stimulates the development of learning systems, from which adults and older adults can learn throughout their lives (UNESCO, 2019).

The pioneer proposal dedicated to the offering of learning programmes exclusive to the adult and elderly audience was the movement of universities open to the third age (Universitè du Trosième Âge - U3A), established in 1973 in France. Since then, the U3As have been spreading globally, developing different or adapted approaches from that originally put forward in France (Formosa, 2019). This is in accordance with Hu (2020), whose study highlights the importance of adjustments in the operational models of universities in order to meet the educational needs of older learners in progressively ageing societies. 
According to Brink (2017), education for older people challenges the perspective of lifelong learning because laterlife learning does not present itself as an extension of adult learning which, in turn, is characterised by its focus on professional abilities. However, the lifelong learning values are the same across all stages of life: knowledge updating, acquisition of new abilities, learning how to use technology, dealing with new and unexpected situations, among others. In recent research, Talmage et al. (2019) propose a model comprised of four main values from the lifelong learning activities designed for the older: learning experience, community environment, learning quality and learning access. However, little research has been dedicated to the investigation of the different types of lifelong learning activities (and life-wide) designed for the older (Yamashita, López, Stevens, \& Keene, 2017).

This scoping review aims to map the lifelong learning activities which are targeted at the older population so to better comprehend the application of the lifelong learning paradigm to practical actions, as well as to contribute to future research for the elaboration of educational models. Background research has not uncovered other reviews exploring such a theme in the literature, neither with the purposes of:

(1) Identifying the types of lifelong learning activities for the older person;

(2) Identifying the challenges regarding the practice of lifelong learning for the older person.

\section{Methodology}

The development of research based on evidence has seen great expansion in the past few years. The method of scoping review is employed in order to recognise or clarify definitions and concepts of a given topic or area of knowledge (Peterson, Pearce, Ferguson, \& Langford, 2017). According to Arksey and O'Malley (2005), scoping reviews can examine the extension and the range of evidence of a specific theme, synthesise and promote research results, identify existing gaps in the literature and determine the value for the posteriori production of a systematic review. Despite the recurring use of this method in the health area, it is also possible to employ it in other areas of knowledge, such as education.

The fundamental stages initially outlined by Arksey and O'Malley (2005) for scoping reviews were, later, revised and further elaborated to offer greater methodological rigour (Peters et al., 2015; Daudt, Van Mossel, \& Scott, 2013; Levac, Colquhoun, \& O'Brien, 2010). Manuals developed by the Joanna Briggs Institute (JBI) clarify in detail the methodological guidelines of scoping reviews (Peters et al., 2020), serving as a complete guide for the development of this type of research (Lockwood, dos Santos, \& Pap, 2019). The Preferred Reporting Items for Systematic documents for Scoping Reviews and Meta-Analysis (PRISMA-ScR) (Tricco et al., 2018) and the nine steps updated by the JBI for conducting scoping reviews (Peters et al., 2020) will be considered in this research, in order to identify the main characteristics or factors related (Munn et al., 2018) to lifelong learning activities for the elderly:

- Step 1 - Definition of objectives and research question;

- Step 2 - Development of inclusion criteria and alignment with the research objectives and question;

- Step 3 - Description of the planned approach to the search for evidence, selection, data extraction and presentation of evidence;

- Step 4 - Search for evidence;

- Step 5 - Selection of evidence;

- Step 6 - Extraction of evidence;

- Step 7 - Analysis of evidence;

- Step 8 - Presentation of results; 
- Step 9 - Summary of evidence in relation to the research objectives and question, conclusions and observations of the implications of the results

\section{Study aim, purpose, and research question}

The primary objective of this review is to answer the following question: how is the lifelong learning paradigm integrated into the educational activities for the older person?

\section{Relevant studies}

As a search strategy for this study, the search period will be between 1972 and 2020 and it will include empirical studies published in English. The starting date was chosen with reference to the publication of the Faure Report, Learning to Be: The World of Education Today and Tomorrow (Faure et al, 1972) by UNESCO, which was produced by the International Commission for the Development of Education.

The studies may present different research designs (descriptive, correlational, semi-experimental and experimental) and are to be included in the scoping review if: (1) published in peer-reviewed journals; (2) they address the concept of lifelong learning in the study or publication; (3) they present as their target population, or study sample, older men and/or women; (4) they propose or present educational activities: formal, non-formal or informal. Articles not subjected to peer reviews, specialists' opinions, editorial letters and books, master's dissertations and $\mathrm{PhD}$ theses will not be included.

\section{Study selection}

Participants: The definition of the old person is culturally constructed and socially determined (Findsen \& Formosa, 2011), thus the age of 60 or $60+$ is to be adopted solely as a reference to order the gathering of data for this research. Those studies with adult sample populations at the ages of 50 to 60 are to be included in this research as the cut-off point in the chronological reference may vary among the publications.

Concept: Lifelong learning is the central concept of this scoping review, which will take into consideration the following conceptual idea of the term: "Lifelong learning is rooted in the integration of learning and living, covering lifelong (cradle to grave) and life-wide learning for people of all ages, delivered and undertaken through a variety of modalities and meeting a wide range of learning needs and demands" (UNESCO, 2014), thus referring to "all learning activity undertaken throughout life, which results in improving knowledge, know-how, skills, competences and/or qualifications for personal, social and/or professional reasons" (UNESCO, 2013. p.39).

Context: This scoping review is to consider studies which include lifelong learning activities undertaken within different contexts and which comprehend the modalities of formal, non-formal and informal education.

Study Types: This review is to include both qualitative and quantitative studies, identified as observational (crosssectional and cohort) and interventional studies (nonrandomised and randomised clinical trials). From the grey literature, recommendations, reports and congress or conference proceedings with political proposals for the development of lifelong learning activities for the older are to be considered.

\section{Study Strategy}

The electronic search is to be conducted in the following databases: AngeLine, ERIC, MedLine, Web of Science and Scopus. A set of English language keywords and their correlated/synonym terms is to be searched in each database by adopting the PCC mnemonic - population, concept, context: "older adults"; "lifelong learning" and "late life learning". The Boolean 
operators OR and AND are to be utilised, being OR for the variations of a term and AND for the combination between two terms (an example of a search conducted in the AgeLine database can be found in Table 1).

Table 1 - Example of search terms selected for the AgeLine database - EBSCOhost Interface.

\begin{tabular}{|c|c|c|}
\hline Terms to capture & Search & Terms \\
\hline $\begin{array}{l}\text { Population } \\
\text { Older Adults }\end{array}$ & All fields & $\begin{array}{l}\text { TX ("older adult*" OR elderly OR "older people" OR aged). Additional limits Search- } \\
\text { Date: From } 1972 \text { to } 2020\end{array}$ \\
\hline $\begin{array}{l}\text { Concept } \\
\text { Lifelong Learning }\end{array}$ & All fields & $\begin{array}{l}\text { TX ("lifelong learning" OR "life-long learning" OR "life long learning" OR "lifelong } \\
\text { education"). Additional limits Search- Date: From } 1972 \text { to } 2020\end{array}$ \\
\hline $\begin{array}{l}\text { Context } \\
\text { Later Life Learning }\end{array}$ & All fields & $\begin{array}{l}\text { TX ("later life learning" OR "later-life learning" OR "later life education" OR "later-life } \\
\text { education" OR "aging education" OR "ageing education" OR "gerogogy" OR } \\
\text { "geragogy" OR "andragogy" OR "adult education" OR "adult learning" OR "permanent } \\
\text { education" OR "continuing education"). Additional limits Search- Date: From } 1972 \text { to } \\
2020\end{array}$ \\
\hline
\end{tabular}

Source: Authors (2021).

The choice of databases and the search strategies used were defined in conjunction with the public university librarian. A manual search in the reference lists of the included studies is also to be conducted so as to identify other evidence which meet the criteria of this study.

Following the search in the databases, the selection process is to undergo three stages. The first is to be performed by two independent researchers based on the title and abstracts of the publications in order to check whether they adhere to the proposed objectives. The second is to be performed while taking into consideration the inclusion and exclusion criteria and, in the event of any disagreements between these two researchers, a third researcher is to be consulted with a view to a consensual resolution. The third stage is to consist of a full reading of the selected studies with the justification for any exclusion being documented.

The selected studies for this scoping review are to be catalogued in the Endnote Web Library database. For a more detailed analysis, the selected studies which present or describe lifelong learning activities for the older are to be organised according to the following modalities: a) formal learning; b) non-formal learning and c) informal learning (Valdés, Pilz, Rivero, Machado, \& Walder, 2014).

\section{Charting the data}

The detailed description of the selection process is to follow the PRISMA-ScR flow diagram, which presents the number of identified records (from the databases and additional sources), the included and excluded texts, as well as the reasons for exclusions. The data extraction process is to be performed by two independent researchers based on the studies and publications included in this research, and by utilising a specific form developed for this scoping review using an MS Excel spreadsheet.

\section{Collating, summarizing, and reporting the results}

At first, the data extraction is to comprise both informative and descriptive items, such as bibliometric data (title, authors' names, year of publication, country of origin, source), characteristics of the study (objective, type of research design, method, participants/sample size, instruments employed, main results and conclusion) and specific information for this scoping review: conceptual idea of lifelong learning, mode of learning (formal, non-formal, informal), context (community, hospital, school, etc.), area of the educational activity (language and digital skills, culture and history, civic engagement, leisure, health), challenges and opportunities in the educational practice, and political recommendations/strategies. 
Following the full reading of the five first studies included in the research, the data extraction form may be adjusted and honed by the research team. The relevant data to address the research question is to be submitted to narrative synthesis and presented in table and diagrammatic format. It should be noted that the last optional stage of consultation with specialists will not be adopted in this scoping review.

\section{Partial Considerations}

The proposal for this scoping review is grounded in the lifelong learning paradigm and in the elderly. In the international debate, lifelong learning is aligned to sustainability and to political, economic and social development of communities, becoming an organising principle in the politico-educational agendas of several countries (UNESCO-UIL, 2014; United Nations, 2015). Indeed, it is possible to note the inclusion of the lifelong learning discourse in various contexts besides the field of education. Regarding the domain of health politics, lifelong learning stands as a fundamental pillar for the promotion of active ageing, with reference to the adoption of healthy attitudes and behaviour, engagement and lived experience in society (ILC-Brasil, 2015; World Health Organization, 2002). However, learning as an intrinsic part of life, and understood as development and transformation of the person integrated within a social system, is a challenging concept. Zhu and Zhang (2019) reinforce the cultural character of lifelong learning activities, which can be directed towards the adaptation, engagement and integration of the elderly in multicultural societies with the aim of promoting active ageing.

Considering the different approaches and functionalities of the concept of lifelong learning (Aspin \& Chapman, 2000), this scoping review is to concentate its investigation on practical proposals or actions regarding lifelong learning activities for the older person so as to better comprehend the subject from the perspective of what it seeks to answer or to offer to this public. The lifelong learning activities are to be described, not critically evaluated, in this scoping review, which is in agreement with such a research method (Lockwood, Santos \& Pap, 2019). Other questions not included in this proposal may be explored in other more specific studies.

Investigations into lifelong learning activities for the older can aid in future research, as it will offer a greater understanding of the learning demands in aging societies or those in a process of demographic transition. In this sense, this scoping review can contribute to the field of educational gerontology by offering information on the types of lifelong learning activities for the older and from which perspectives the new educational paradigm has been adopted.

The protocol for this scoping review has been developed by considering the thematic pertinence of lifelong learning as well as the relevance of field research on the education for the adult and the older. The development of a scoping review protocol is essential as it describes and details the objectives, the research question, the inclusion criteria and the stages to be performed throughout the research (Lockwood, Santos \& Pap, 2019). It is expected that this scoping review is to be concluded within 10 months - as it can be seen in the schedule presented in Table 2 below.

Table 2. Timeline proposed for scoping review completion.

\begin{tabular}{clll}
\hline Stage & Task & Time & Staff \\
\hline 1 & Identify research question and define the protocol & Months 1-2 & KF, MC, SB, HG \\
\hline 2 & Preliminary identification of relevant studies & Month 3 & KF, MC \\
\hline 3 & Study selection & Months 4-5 & KF, (MOC), MC \\
\hline 4 & Charting the data & Month 6 & KF, MC \\
\hline 5 & Summarizing and reporting the results & Months 7-8 & KF, MC \\
\hline 6 & Write-up of scoping review & Months 9-10 & KF, MC, SB, HG \\
\hline
\end{tabular}

Source: Authors (2021). 


\section{Acknowledgments and Funding}

The authors gratefully acknowledge the contribution of Ana Paula Morais de Oliveira, a librarian at the Universidade Estadual de Campinas (Brazil), for her specialized support during the search process. This research receives financial assistance from the Coordination for the Improvement of Higher Education People (CAPES), through the Graduate Program in Gerontology at the School of Arts, Sciences and Humanities at the University of São Paulo.

\section{References}

Arksey, H., \& O’Malley, L. (2005). Scoping studies: Towards a methodological framework. International Journal of Social Research Methodology, 8(1), 1932. https://doi.org/10.1080/1364557032000119616

Aspin, D. N., \& Chapman, J. D. (2000). Lifelong learning: Concepts and conceptions. International Journal of Lifelong Education, 19(1), 2-19. https://doi.org/10.1080/026013700293421

Brink, S. (2017). Learning in Later Years in the Lifelong Learning Trajectory. Journal of Intergenerational Relationships, 15(1), 14-25. https://doi.org/10.1080/15350770.2017.1260391

Cooper, S., Cant, R., Kelly, M., Levett-Jones, T., McKenna, L., Seaton, P., \& Bogossian, F. (2019). An Evidence-Based Checklist for Improving Scoping Review Quality. Clinical Nursing Research. https://doi.org/10.1177/1054773819846024

Daudt, H. M. L., Van Mossel, C., \& Scott, S. J. (2013). Enhancing the scoping study methodology: A large, inter-professional team's experience with Arksey and O'Malley's framework. BMC Medical Research Methodology, 13(48), 1-9. https://doi.org/10.1186/1471-2288-13-48

Dehmel, A. (2006). Making a European area of lifelong learning a reality? Some critical reflections on the European Union's lifelong learning policies. Comparative Education, 42(1), 49-62. https://doi.org/10.1080/03050060500515744

Delors, J., Al Mufti, I., Amagi, I., Carneiro, R., Chung, F., Geremek, B., \& Nanzhao, Z. (1996). Learning: the treasure within. Report to Unesco of the International Commission on Education for the Twenty-first Century (highlights). Retrieved from https://unesdoc.unesco.org/ark:/48223/pf0000109590

Elfert, M. (2015). UNESCO, the faure report, the delors report, and the political Utopia of lifelong learning. European Journal of Education, 50(1), 88-100. https://doi.org/10.1111/ejed.12104

Faure, E.; et al (1972). Apreendre à être. Fayard, UNESCO. https://unesdoc.unesco.org/ark:/48223/pf0 000132982?posInSet=1\&queryId=e9762211-ab69$4 \mathrm{f} 34-87 \mathrm{~cd}-8 \mathrm{c} 6 \mathrm{abee} 7 \mathrm{a} 56 \mathrm{c}$

Findsen, B., \& Formosa, M. (2011). Lifelong Learning in later life: a handbook on older adult learning. Rotterdam: Sense Publishers https://doi.org/10.4135/9781446269916.n22

Formosa, M. (2019). Universities of the Third Age. In Encyclopedia of Gerontology and Population Aging (pp. 1-6). https://doi.org/10.1007/978-3-319$69892-2$

Hu, H.-M. (2020). Facing an Aging Society: Taiwan's Universities in crisis. Gerontology and Geriatrics Education, 41(2), 233-241. https://doi.org/10.1080/02701960.2018.1428576

ILC-Brasil. (2015). Envelhecimento Ativo: Um Marco Político em Resposta à Revolução da Longevidade. ILC-BR. Retrieved from http://ilcbrazil.org/portugues/noticias/active-ageing-a-policy-framework-in-response-to-the-longevity-revolution/

Levac, D., Colquhoun, H., \& O’Brien, K. K. (2010). Scoping studies: Advancing the methodology. Implementation Science, 5(1), 1-9. https://doi.org/10.1186/1748-5908-5-69

Lockwood, C., Santos, K. B., \& Pap, R. (2019). Practical Guidance for Knowledge Synthesis: Scoping Review Methods. Asian Nursing Research, 13, 287294. https://doi.org/10.1016/j.anr.2019.11.002

Peters, M. D. J., Godfrey, C. M., Khalil, H., McInerney, P., Parker, D., \& Soares, C. B. (2015). Guidance for conducting systematic scoping reviews. International Journal of Evidence-Based Healthcare, 13(3), 141-146. https://doi.org/10.1097/XEB.0000000000000050

Peters, M., Godfrey, C., McInerney, P., Baldini Soares, C., Khalil, H., \& Parker, D. (2017). Chapter 11: Scoping reviews. In E. Aromataris \& Z. Munn (Eds.), Joanna Briggs Institute Reviewer's Manual (4th ed.). Retrieved from https://reviewersmanual.joannabriggs.org/

Peterson, J., Pearce, P. F., Ferguson, L. A., \& Langford, C. A. (2017). Understanding scoping reviews: Definition, purpose, and process. Journal of the American Association of Nurse Practitioners, 29(1), 12-16. https://doi.org/10.1002/2327-6924.12380

Talmage, C. A., Hansen, R. J., Knopf, R. C., Thaxton, S. P., McTague, R., \& Moore, D. B. (2019). Unleashing the Value of Lifelong Learning Institutes: Research and Practice Insights From a National Survey of Osher Lifelong Learning Institutes. Adult Education Quarterly, 69(3), 184-206. https://doi.org/10.1177/0741713619834651

Tam, M (2018). Lifelong Learning for Older Adults: Culture and Confucianism. In M. Milana et al (Eds.) The palgrave international handbook on adult and lifelong education and learning (Part III. pp. 857-878). London: Palgrave Macmillan https://doi.org/10.1057/978-1-137-55783-4 
Research, Society and Development, v. 10, n. 14, e143101421947, 2021

(CC BY 4.0) | ISSN 2525-3409 | DOI: http://dx.doi.org/10.33448/rsd-v10i14.21947

Tricco, A. C., Lillie, E., Zarin, W., O’Brien, K. K., Colquhoun, H., Levac, D., \& Straus, S. E. (2018). PRISMA extension for scoping reviews (PRISMA-ScR): Checklist and explanation. Annals of Internal Medicine, 169(7), 467-473. https://doi.org/10.7326/M18-0850

UNESCO-Institute for Lifelong Learning. (2014). Learning Cities International Conference. Lifelong learning for all: Inclusion, prosperity and sustainability in cities. Conference Report 21-23 October 2013, Beijing, China. (p.68). Hamburg: UNESCO-UIL.

UNESCO-Institute for Education. (1999). Glossary of adult learning in Europe (p. 130). p. 130. Retrieved from http://uil.unesco.org/adult-education/glossaryadult-learning-europe

United Nations Educational Scientific and Cultural Organization. (2013). Glossary of Curriculum Terminology (pp. 1-65). 1-65. www.ibe.unesco.org

United Nations Educational Scientific and Cultural Organization. (2014). Technical Note Lifelong learning. UNESCO Institute for Lifelong Learning. from http://uil.unesco.org/fileadmin/keydocuments/LifelongLearning/en/UNESCOTechNotesLLL.pdf

United Nations Educational Scientific and Cultural Organization. (2019). 4th Global Report on Adult Learning and Education: leave no one behind: participation, equity and inclusion. UNESCO Institute for Lifelong Learning. http://uil.unesco.org/adult-education/global-report/fourth-global-report-adultlearning-and-education

United Nations. (2015). Transforming our world: the 2030 Agenda for Sustainable Development. In A/RES/70/1. Resolution adopted by the General Assembly on 25 September 2015 https://sustainabledevelopment.un.org/post2015/transformingourworld

Valdés, R., Pilz, D., Rivero, J., Machado, M. M., \& Walder, G. (2014). Contribuições conceituais da educação de pessoas jovens e adultas: rumo à construção de sentidos comuns na diversidade / Organização de Estados Ibero-americanos e Instituto da UNESCO para a Aprendizagem ao Longo de Toda Vida. Goiânia: Ed. UFG. http://confinteabrasilmais6.mec.gov.br/images/documentos/contribuicoes_conceituais.pdf

Wang, M., Yuan, D., \& Weidlich, M. (2017). Do the demands of the global forces shape local agenda? An analysis of lifelong learning policies and practice in China. Asia Pacific Education Review, 18(2), 219-226. https://doi.org/10.1007/s12564-017-9485-6

World Health Organization. (2002). Active ageing: a policy framework. https://www.who.int/ageing/publications/active_ageing/en/

Yamashita, T., López, E. B., Stevens, J., \& Keene, J. R. (2017). Types of Learning Activities and Life Satisfaction among Older Adults in Urban CommunityBased Lifelong Learning Programs. Activities, Adaptation and Aging, 41(3), 239-257. https://doi.org/10.1080/01924788.2017.1310583

Zhu, Y., \& Zhang, W. (2019). Active learning for active ageing: Chinese senior immigrants' lifelong learning in Canada. Educational Gerontology, 45(8), 506-518. http://search.ebscohost.com/login.aspx?direct=true\&db=gnh\&AN=EP138830481\&lang=pt-br\&site=ehost-live. 